\title{
ARTE MEXICA
}

\section{Durdica Segota}

Il complejo cultural de la civilización mexica está integrado por una serie de instituciones cuyas características -en la mayoría de los casos- difieren radicalmente de las de la civilización occidental moderna. No solamente existen distinciones en cuanto al número y nivel de desarrollo de esas instituciones, sino también la manera como éstas se articulan. Obviamente, varía también el grado de su autonomía.

Puesto que el arte es un producto social, varía la manera y eficacia de sus vínculos con otras instancias de la misma sociedad; estos vínculos cambian de una sociedad a otra y de un momento histórico a otro; es decir, cambian las condiciones de la producción artística, la posición social del artista y la función misma de la obra que afecta al espectador con su carga emocional e ideológica.

Estas razones nos conducen a considerar al arte en su justa dimensión histórica y no en su "naturaleza", o "esencia", siempre iguales a sí mismas.

Muchas de las obras a las que hoy día nuestra cultura denomina "arte", tuvieron en diferentes sociedades y épocas un significado, valor y función distintos. Nos referimos sobre todo a la producción artística de las cultutas que irrumpieron en la historia europea en la época moderna, general. mente como pueblos colonizados.

El arte de las cultuxas precapitalistas y no occidentales reciben a menudo el calificativo de "primitivo", y algunos autores trataron de encontrar sus características comunes. Esta búsqueda no fue muy feliz, puesto que las artes llamadas primitivas no tienen cualidad alguna en común ni en cuanto a su forma ni en cuanto a su contenido. A la vez, las condiciones de la producción artística varían tanto de una sociedad "primitiva" a otra, como varían las funciones que cumplen las obras en las sociedades respectivas.

No ignoramos que hoy las piezas procedentes del área cultural mesoamericana se encuentran dispersas en varias partes del mundo, muchas veces en los museos dedicados precisamente a este arte "primitivo". Nosotros no aceptamos desde luego este término para la sociedad mexica del siglo xv y principios del XvI, dado el tipo de estructuras sociopolíticas y económicas, y la naturaleza general de su ideología.

In nuestra aproximación al arte mexica no hacemos distinción entre los términos artista y artesano, en virtud de que consideramos que la dicotomía artista-artesano sólo se planteó a raíz del surgimiento del 
concepto moderno del arte, en el Renacimiento, y al analizar una realidad específica: la europea.

En resumen, desde entonces se distingue artesanía, entendida como habilidad y manejo técnico, del concepto de arte, al que se le da una connotación de capacidad de creación intelectual.

Desde este punto de vista ¿en la ciudad de México-Tenochtitlan trabajaban artistas, o artesanos, o ambos?

Para la sociedad mexica, el análisis de este problema podría hacerse, tal vez, por medio de la diferenciación de la producción artística especializada, ligada a la ciudad y a las necesidades de la clase dominante, los pipiltin, por un lado; $y$, por el otro, la producción artesanal doméstica, campesina.

Por ahora, optamos por los términos arte y artista. Nuestra elección se debe, más que nada, al deseo de evitar un vocablo que hoy tiene cierta carga peyorativa, ya que la artesanía sigue considerándose como mera habilidad técnica; de manera semejante, se considera al artesano como carente de una capacidad creativa o de inventiva intelectual.

La información que nos proporcionan las fuentes escritas acerca de la producción artística pertenece a lo que diversos autores contemporáneos llaman, atendiendo a su procedencia, "arte esencialmente metropolitano"; otros lo denominan "arte de la élite" por su relación con el conocimiento de los tlamatinime, o bien, por su patrocinio y finalidad, se le dice "arte oficial". Todas estas denominaciones se deben a que las excavaciones arqueológicas fueron llevadas a cabo principalmente en el sitio que una vez fuera el centro de México-Tenochtitlan (hoy centro de la ciudad de México), en el Tlaxicco Onoc, en el corazón de la ciudad e "imperio" mexicas.

Para aclarar esta situación recordemos la manera peculiar de solución urbanística de esta metrópoli, su división cuatripartita en "barrios", llamados Cuepopan o Tlacuechiuhcan (al noroeste), Moyotla (al suroeste), Zoquiapan o Teopan (al sudeste), y Atzacualco (al noreste). Es la división del mundo, son los cuatro rumbos del universo, en cuyo centro o intersección estaba la quinta región marcada por el recinto del Templo Mayor, resguardado por el coatepantli o "muro de serpien. te", de una extensión aproximada de $500 \times 500 \mathrm{~m}$. Dentro del Templo Mayor, dice Sahagún, había setenta y ocho diferentes construcciones, entre las cuales destacaban los basamentos escalonados, soportes para los templos dedicados a las diversas deidades mexicas. El más importante por su tamaño correspondía desde luego a los jerarcas del pan- 
teón, a Huitzilopochtli y a Tláloc Había allí mismo otras edificaciones, como los calmécac, que algunos autores contemporáneos traducen como "escuela", mientras otros prefieren interpretar su función como casas donde se realizaban diversas funciones sacerdotales y los autosacrificios de los pipiltin; sitios para el sacrificio y ofrendas, varios. tzompantli o tingleras de cráneos, el teotlachco o juego de pelota divino, etcétera. En las proximidades de este conjunto religioso estaban las casas nuevas de Motecuhzoma, el palacio de Axayácatl, y el palacio del Gihuacóatl. Pues bien, precisamente de esta zona de la ciudad proceden la mayoría de las obras de arte que hoy adornan la sala mexica del Museo Nacional de Antropología; es decir, del centro religioso y ceremonial cuyo culto era atendido por los pipiltin y de la parte urbana habitada por los mismos.

Los barrios que mencionamos también tenían su centro ceremonial, pero de dimensiones e importancia menores. Fuera de estos núcleos religiosos habitaba la gente que constituia la gran mayoría de la población de Tenochtitlan, los macehualtin, la gente del pueblo, de diferentes ocupaciones y especializaciones, entre ellas las artísticas. Tenían, sin embargo, en común una posición social y económica semejante; eran productores de la riqueza creada por el trabajo excedente, obligatorio. El macehual levantaba las construcciones que le servían de vivienda, y las ejecutaba en materiales perecederos; sus casas exan de adobe, madera y paja; sus objetos de uso ritual o funerario eran formas sencillas de barro, de madexa o de masa de semillas. Estos materiales, evidentemente, no resistieron el paso de los siglos, como sucedió con los productos del arte "oficial", ejecutados generalmente en materiales resistentes y duraderos, como la piedra utilizada en la escultura monumental. El campesino mexica sólo podía satisfacer sus necesidades con medios modestos que conducían, obviamente, a productos también modestos, por lo general. Además, como veremos más adelante, el trabajo artístico en materiales duraderos requería la adquisición previa de éstos, de una organización especifica del trabajo, de gran especialización técnica y del tiempo necesario para la ejecución de la obra. Todos estos aspectos y condiciones estaban fuera de las posibilidades de los macehualtin.

No queremos decir con esto que en Tenochtitlan existieron dos artes radicalmente distintos: un arte de la élite y un arte del pueblo. Creemos que las manifestaciones artísticas de las dos clases sociales mexica, los pipiltin y los macehualtin, tuvieron estructura y función semejantes. Pueden tener diferencias en cuanto a la complejidad iconográfica, cali- 
dad técnica del trabajo y acabado, o en el material empleado, pero no en cuanto al carácter general y su función. Ahora bien, es un hecho que los pipiltin dieron rasgos específicos a la ideología, a la religión y también a las manifestaciones artísticas mexicas; esto resulta lógico si tomamos en cuenta que la clase que ejerce el poder económico dominante es al mismo tiempo la fuerza espiritual dominante.

\section{Formación del estilo artístico}

\section{a) Factores externos}

La formación del estilo artístico mexica corresponde a varias causas. En primer lugar, desde luego, a la necesidad de expresión y comunicación propios, de lo cual hablaremos más adelante, pero hay que tomar en cuenta también algunos factores externos.

Si bien hoy día la expresión artística mexica es prácticamente inconfundible con los demás estilos mesoamericanos, mánifiesta un vínculo indudable con otras culturas $\mathrm{y}$, sobre todo, con las que la precedieron en el mismo ámbito geográfico: Teotihuacan y Tula. Los mexicas recuperan esta tradición histórico-cultural y se apropian de ella a través de una reelaboración ideológica del pasado.

Así, Teotihuacan y Tula están presentes en sus mitos y su historia y también en sus expresiones artísticas; lo observamos en una serie de soluciones formales y en la iconografía. Sabemos, inclusive, que no es extraño para un arqueólogo encontrar en los cimientos del Templo Mayor objetos procedentes de Teotihuacan. Por ejemplo, sus serenas, hieráticas y estilizadas máscaras hechas en piedra; estas características se repetirán en las máscaras mexicas, claro, con un selìo y estilo propios.

Aun los objetos más antiguos, hechos por los olmecas, aparecen en los entierros y entre los escombros de Tenochtitlan. A nuestro modo de ver, fueron estos últimos los que enseñaron a los mexicas el valor y la suavidad de la línea curva, patentes en las esculturas como la del gran "Cuauhxicalli" zoomorfo que nos recibe a la entrada de la sala mexica del museo de Antropología.

Hay otra causa externa e indirecta en la formación del estilo mexica y es la influencia de los pueblos conquistados por ellos, caracterizados por su heterogeneidad étnica y lingüística, así como por la diversidad de niveles de desarrollo cultural. Estos influían al arte mexica a través de los objetos artísticos que llegaban a Tenochtitlan como parte del tributo o de intercambio comercial. 
Lo que llamamos la influencia directa es la presencia de los artistas extranjeros, no nahuas, en la ciudad tenochca. Estos eran invitados con el encargo específico de trabajar en la producción artística; entre ellos los más estimados por su conocimiento y habilidad técnica parece que fueron los mixtecas.

Algunos objetos recientemente descubiertos en el Templo Mayor, como dos grandes vasos de barro decorados con relieves estilo códice mixteco, hablan a favor de estas influencias y confirman la información de las fuentes documentales.

\section{b) Factores internos}

Antes de iniciar el análisis del proceso de producción artística y de las funciones sociales del arte, quisiéramos subrayar algunos de los elementos que constituyeron los factores internos de la formación del estilo mexica.

La inalterabilidad de las condiciones de producción y la inmovilidad de las relaciones sociales existentes en la cultura mexica se manifestó en su arte a través de una permanencia de cánones artísticos o en la resistencia a modificaciones fundamentales de su expresión. Durante los llamados cien años del Pueblo del Sol, no se produjeron cambios de la estructura social misma y lo estático del orden social dio un carácter de rigidez y hieratismo a su estilo.

Sin embargo, a partir de la liberación de la ciudad de México-Tenochtitlan del dominio de Azcapotzalco hubo una manifestación interna, una refuncionalización de las estructuras sociales. Ésta produjo una mayor división del trabajo que incluyó la especialización artística y dio por resultado un perfeccionamiento del manejo técnico; o, como algunos autores lo llaman, un preciosismo en la expresión.

Observemos las grandes figuras de Tláloc que aparecieron hace poco en el Templo Mayor. Son estatuas labradas toscamente y pertenecen a una época temprana, y contrastan con las de un periodo más tardío, como eI "Xólotl" del museo de Stuttgart, o el "Quetzalcóatl" del Museo del Hombre de París. El acabado y pulido de estas últimas son mucho mayores y más cuidadosos. Sin embargo, esta diferencia no constituye, de ninguna manera, un criterio suficiente para establecer una periodificación del arte mexica, la que, por cierto, es tarea por hacerse.

Otro de los cambios sociales de importancia fue la paulatina institucionalización de la guerra. En el arte, no se abandonaron, desde luego, los temas ligados a la producción agrícola y la fertilidad. Las vasijas 
y efigies de Tláloc, por ejemplo, son numerosas en todas Ias épocas. Pera el tema bélico se acentúa cada vez más. La lucha puede ser cósmica: así lo registra la "Piedra del Sol", popularmente llamada "Calendario Azteca", o las cihuateteo, fieles acompañantes, protectoras del sol vespertino. Sin embargo, no sólo en el universo existe la batalla cotidiana; también la sociedad mexica está en la guerra y la "Piedra de Tizoc" ha dejado memoria de los combates y conquistas.

\section{El tributo: materiales y materias primas}

El tributo constituyó un factor importantísimo en el desarrollo de ia cultura mexica y, al parecer, la base misma de su economía. Lo que a nosotios nos interesa en este momento es su relación directa con la producción artística.

Como parte del tributo había un gran número de productos elaborados artísticamente; entre ellos, como lo muestra la Matricula de Tributos, muchas piezas hechas por los artistas de los pueblos conquistados. Así, mantas bordadas, trajes de guerreros hechos de pieles de tigre o de plumas, escudos, cuentas de piedras preciosas o semipreciosas, adornos de oro y otros objetos suntuarios.

Además de las piezas producidas en diferentes poblaciones del dominio mexica, a la metrópoli entraban como tributo los cargamentos de materiales y materias primas necesarias para la producción artística. Tanto los materiales -o sea, objetos obtenidos de la naturaleza en su estado puro (por ejemplo, piedras para la escultura monumental) -, como las materias primas $\mathfrak{u}$ objetos naturales ya elaborados, productos ellos mismos del trabajo (así, pieles curtỉas o mantas de algodón) entraban a Tenochtitlan como tributo. De esto dependía prácticamente la mayor parte de la producción artística de los mexicas: su arquitectura, escultura de bulto o en relieve, arte plumai ia, orfebrería, trabajo de piedras preciosas, bordado de mantas, etcétera. Sin ello hubiera sido imposible la abundancia y suntuosidad alcanzadas por lo que hoy llamamos el arte mexica. $Y$ precisamente con el ingreso constante y abundante de los tributos, en el tiempo de Motecuhzoma/Xocoyotzin comienza la proliferación de la producción artística.

E1 artista podía obtener sus materiales y materias primas también de los pochteca o comerciantes: uno y otros constituían oficios estrechamente ligados. Los pochteca abastecían a los tolteca, o sea a los artistas, de materias primas y vendían a su vez, los objetos hechos por éstos en 
Tenochtitlan; ambos, producción artística y comercio, eran organizados y controlados por el Estado.

El tributo fue -como se dijo- de importancia primordial para la arquitectura y la escultura mexicas. Parece evidente que por la dificultad implícita en el transporte de los materiales para estas artes, se consideró suficiente el tributo de los pueblos vecinos, tanto de aliados, como Tezcoco y Tacuba, como de los señoríos subyugados de la zona lacustre. Así, en tiempo de Motecuhzoma Ilhuicamina, al construirse el templo de Huitzilopochtli, tezcocanos, tecpanecas, chalcas y xochimilcas tuvieron que contribuir con piedra, cal, arena y madera. Sin embargo, pueblos más lejanos, como los de la tierra caliente, tenían que aportar arena y cal. La madera para construcción, esto es, las vigas grandes, planchas y pilares por ejemplo, se señala en el códice (Matrícula de Tributos, lámina XII) como uno de los tributos de los pucblos de Tecpan, Chapolmoloyan, Coatepec y otros (hoy, en el Estado de México).

Los pueblos cumplían con regularidad con los tributos impuestos bajo la amenaza constante de los jefes y guerreros mexicas. Era difícil ser vecino de éstos y estar libre de su dominio. El peligro de conquista era constante. Así, cuando se enteraban los dueños del altiplano que en alguna provincia o señorío independiente existía riqueza de un material determinado que ellos necesitaban y del que carecían, usaban abiertamente la fuerza. Por ejemplo, el ejército mexica invadió Tototepec y Quetzaltepec cuando supieron que alli abundaban arenas apropiadas para trabajar la piedra, y que además "había esmeril para bruñirlas y ponerlas muy limpias y resplandecientes"; fray Diego Durán añade que eran caras y difíciles de obtener.

No obstante esto, el joven, arrogante y pujante pueblo mexica trataba de aparentar su firme decisión de llevar buenas relaciones con sus vecinos. Este fue el caso de los chalcas, pueblo de gran tradición escultórica y aún no subyugado Los mexicas se dirigían a ellos "... no mandándoles, sino suplicándoles con humildad, piedras grandes de las que carecemos, para algunas esculturas y figuras que queremos para hermosear el templo...", según nos cuenta el mismo Durán. Chalco se rehúsa y surge la guerra que los convierte en nuevos tributarios de la nación invencible hasta aquel momento.

$\mathrm{La}$ evolución y el desarrollo de las sociedades occidentales se caracterizan generalmente por el progreso tecnológico. Por el contrario, en las sociedades de tecnología simple, y también en la sociedad mexica, el trabajo humano vivo representa la mayor parte del valor de los pro- 
ductos. El tributo en forma de trabajo era tan importante como el tributo en forma de materiales y materias primas. Nos referimos aquí, sobre todo, al tributo en trabajo que se exigía para la construcción de obras públicas en Tenochtitlan: los diques, puentes, edificios destinados al culto y al ritual, los edificios públicos, las viviendas de los pipiltin y la producción de la escultura.

Según Tezozómoc, Axayácatl reunía trabajadores de Tacuba, Cuautlan, Culhuacan, Coyoacan, Chalco, Mizquic ...., es decir, pueblos vecinos.

Pero, al ser conquistados Guextlan y Tuxpan por el Huehue Motecuhzoma, los mismos cuextecas (o huastecas) debian reconstruir el templo de Huitzilopochtli elevando su altura y rehaciendo sus gradas. Una vez concluido el trabajo por los cuextecas, estos últimos fueron sacrificados en el templo que construyeron.

El pueblo mexica también contribuía con el tributo de trabajo. Así, cuando Motecuhzoma Xocoyotzin quiso que se buscara material para una nueva estatua para el templo de Huitzilopochtli, ordenó a su Gihuacóatl que llamara a todos los canteros y albañiles de los cuatro barrios, Teopan, Moyotlan, Atzacualco y Cuepopan, para que la labrasen.

Como dijimos, los materiales para la construcción a veces fueron traídos desde lejos, lo cual requería una movilización de gran cantidad de gente. Igualmente se organizaba un trabajo masivo para el acarreo de las grandes piedras necesarias a los escultores.

Una de las épocas más importantes para la construcción fue la del mandato del tlatoani Ahuizotl. Se había inundado la capital tenochca y los jefes tuvieron que mudarse de la ciudad por el mal estado de sus palacios. Debido a esto se organizó la reconstrucción completa de la misma. Fue tal vez el periodo de trabajo más intenso de toda la historia mexica. Acudieron muchos vasallos para trabajar en el levantamiento de los edificios y en diversos proyectos de ingeniería.

Tezozómoc narra que durante este periodo se juntaban hasta cincuenta mil indios con sogas gruesas y que fueron a sacar una gran peña de la falda de la sierra de Coyoacan. El autor tal vez exagera el número, pero sea cierto o no este dato, de cualquier manera, el número de personas empleadas en el transporte debió haber sido tan grande como el peso de las piedras y lo precario de la técnica usada. Las piedras fueron transformadas posteriormente por los artistas mexicas y se convirtieron en lo que nosotros conocemos hoy como la escultura monumental; de ésta, una que nos asombró hace poco por su excelente calidad artística fue el relieve de composición circular que representa 
a Coyolxauhqui (se encuentra in situ, al pie de la gran pirámide del Templo Mayor).

\section{c) El trabajo como control de la población}

Aunque sólo hemos dado unos cuantos ejemplos, sabemos que el tributo de trabajo fue una práctica común y constante; al parecer, el estado mexica se sirvió de ella para el control de la población, sobre todo en el periodo del año en el cual no se requería la ocupación constante de los macehualtin en el campo o en sus chinampas, es decir, en los trabajos agrícolas. Mas para el macehual este tributo representaba una obligación ardua, puesto que se trabajaba sin reposo; el cihualcóatl Tlacaélel revisaba y agilizaba personalmente las obras; no dejaba descansar a la gente. La mayoría no recibía recompensa alguna; sólo los oficiales eran considerados en la distribución de mantas, ceñidores, cacao, chile, frijol, "esclavos" y otros diversos premios.

La organización de los trabajos incluía obviamente también el mantenimiento de los trabajadores. Así, mientras treinta canteros trabajaban en la obra, los de Chalco les daban de comer. En algunos casos la comida parece haber sido apenas suficiente, pues se les proporcionaba sólo una vez al día, "a la caída de la tarde", dice Chimalpain, "a estos diversos pueblos que tenía Tenochtitlan aposentados en la obra".

Tanto el tributo de trabajo como el de materiales fue seguramente un gran peso para los vasallos y un elemento que debilitaba económicamente a las provincias afectadas. Después de conocer todos estos datos, rio resulta sorprendente que se hayan producido rebeliones contra los mexicas, tales como los levantamientos de los chalcas y de los huastccos, entre muchos otros.

Apuntaremos aquí también el acarreo de una piedra desde Ayotzinco, durante el gobierno de Motecuhzoma Xocoyotzin "Según la tradición indígena consignada en las fuentes coloniales, la piedra al pasar el puente de Xoloco se hunde y regresa sola a su lugar originario, además se dirige a los indígenas hablándoles de un presagio nefasto para Tenochtitlan. El hecho es interesante porque demuestra la creencia en la forma anímica de trabajo, según la cual los entes sobrenaturales participan también en la realización de algunas obras materiales. Éste parece haber sido un fenómeno muy común en la sociedad mexica y no es difícil suponer que hay en él importantes implicaciones ideológicas (manejadas por los pipittin), con el fin de aliviar el peso del trabajo. y extraer la fuerza máxima de los súbditos. 


\section{Encargo de las obras}

Después de haber expuesto brevemente la manera como se adquirían las materias primas y los materiales necesarios para la arquitectura y la escultura y cómo se organizaban los trabajos masivos, trataremos de señalar la intervención de los pipiltin en los momentos específicos de la producción artística misma, a través de encargos especiales y la supervisión de las obras en los momentos de su elaboración.

Generalmente encargaban las obras los jefes supremos, el huey tlatoani y su cihuacóatl. Por ejemplo, después de la batalla de Tlatelolco, Axayácatl deseaba glorificar las hazañas de sus guerreros y destacar el apoyo recibido de los dioses, para lo cual, propuso a Tlacaélel mandar hacer nuevas esculturas, mayores en tamaño y de mejor calidad. Tlacaélel asintió y se encargó de la organización del trabajo. Desgraciadamente, en este caso ni Tezozómoc ni otros autores describen Ias obras mismas; el interés por los temas prehispánicos ya habia desaparecido.

En otra ocasion, el Huey Motecuhzoma encarga que se esculpa una imagen suya en la roca viva de Chapultepec.

Los encargos tenían una importancia primordial, pues manifiestan claramente qué tipo de obras se fomentaba en la sociedad mexica y quién las promovía. Podemos suponer que toda la arquitectura y escul. tura hallada en lo que una vez fuera el Templo Mayor fue hecha por encargo. En estos casos la presencia de la mediación de los pipiltin resulta bastante obvia; sin embargo, existía en todas las artes. Si elegimos siempre los ejemplos de la arquitectura o la escultura, es porque nuestras fuentes escritas se limitan prácticamente a este tipo de producción artística.

\section{Supervisión de las obras}

El tlatoani no sólo encarga la obra e indica lo que debe representar sino que es muy común que vigile personalmente su ejecución. El desafortunado Chimalpopoca, por ejemplo, fue sorprendido por sus enemigos piecisamente en el momento en que revisaba el trabajo de unos escultores que ejecutaban una imagen en piedra. Como señala Durán, Axayácatl dedicaba también una parte de su tiempo a la revisión de las labores artísticas.

Muchas de estas obras constituyeron en la sociedad mexica una parte del tributo que ofrecían los pipiltin a los dioses. En ellas se plasmaban símbolos y conocimientos y la producción de éstos fue exclusiva de la 
clase dominante. Hubo incluso una discriminación de determinados elementos religiosos, conocimientos que colocaban a la clase que los poseía por encima de los macehualtin. Precisamente, de lo privativo de conocimientos derivaba el privilegio de comunicación con los dioses. Los pipiltin eran los únicos realmente capacitados para ofrecer este tributo.

No sólo el contenido de un cuauhxicalli era el tributo, sino también el cuauhxicalli mismo, con sus relieves de hilera de cráneos o con las imágenes de los animales asociados con el inframundo y la noche.

El tlatoani y el cihuacóatl o algún otro miembro de la nobleza supervisaban la ejecución de las obras porque ellos eran los responsables directos de la eficacia del tributo. Un signo o símbolo mal puesto, un atributo de la deidad olvidado son malos augurios y vuelven ineficaz el trabajo y la obra. Por lo mismo, castigaban severamente a los artistas por los errores cometidos.

Los pipilitin reciben el tributo en especie o en trabajo y ellos a su vez tributan a los dioses; es la manera como se elabora y establece una reciprocidad entre las dos clases y con ello cl equilibrio social.

El artista de Tenochtitlan era macehual, pero no trabajaba la tierra, sino que se dedicaba a su labor de tiempo completo. No era dueño de las materias primas ni tampoco de los productos de su trabajo. Producía por encargo y para necesidades sociales específicas. Su trabajo fue obligatorio, como lo fue también la buena calidad de las obras. Conoce. mos testimonios de castigos -destierro o muerte en los casos extremosaplicados a los artistas que no cumplían satisfactoriamente con su deber.

Poseían conocimientos específicos que aplicaban en la ejecución de sus obras. Este era su tributo a la sociedad y esto a su vez les daba dere. cho a participar en la redistribución de lo recaudado por la administración del Estado mexica.

En otras palabras, había una relación de reciprocidad entre el Estado y el artista: éste tributaba su trabajo especializado y se beneficiaba, él y toda su familia, de la redistribución del tributo.

Ahuizotl, después de repartir mantas y ceñidores a los soldados, capitanes, mayordomos, ministros de los templos y viejos de la ciudad, se dirige a los artistas que la han engalanado para una fiesta solemne de Huitzilopochtli y les entrega joyas y mantas bordadas. Reciben también enaguas, huipiles, sandalias, tocados, etcétera. Los plateros, escultores, plumarios, pintores, reciben mantas y ceñidores lujosos conforme al oficio de cada uno.

A veces, ciertamente parece que "los obsequios" se reducían a las 
insignias, objetos de lujo o "preseas de honra". Sin embargo, Tezozómoc amplía la noticia acerca de la misma fiesta y agrega información sobre la repartición de canoas de maíz, huauhtli, chía, chile, frijol, envoltorios de almendras de cacao, "esclavos", y demás anexo y perteneciente al menester de sus casas. Inclusive, Motecuhzoma llegó a entregar casas a los amantecas y les puso taller para que ejerciesen su oficio.

De esta manera, los gobernantes intercambian sus ingresos (plustrabajo), por el trabajo.

El artista mexica que trabajaba en Tenochtitlan frecuentemente era habitante de la misma urbe.

Sin embargo, y de ello tenemos muchos testimonios documentales del siglo xvi, también era común invitar a los artistas procedentes de otras regiones, en primer lugar de aquellas que formaban parte del huey tlatocáyotl, o sea, del conjunto de los dominios mexicas. Estos artistas participaban en la ejecución de ciertas obras de arquitectura, escultura y otras artes.

Los artistas invitados llegaban de Azcapotzalco y Coyoacán; eran conocidos y codiciados los escultores procedentes de Chalco, los pintores de Malinalco y de Tierra Caliente. Acudían también los de Oaxaca - los mixtecos-, y se tenía en alta estima a los olmeca-uixtotin. También eran muy conocidos los lapidarios de Tlatelolco.

No era esta una práctica exclusiva de los mexicas; sabemos también que las demás ciudades de la Triple Alianza solian recibir: artistas foras. teros. Así, Netzahualcóyotl invitó a varios de éstos a Texcoco.

A su vez, los artistas tenochcas solian salir de Tenochtitlan para ejercer su oficio en otras partes, en donde se necesitaba de sus habilidades.

Basamos este artículo sobre la producción artística mexica fundamentalmente en las fuentes documentales. Éstas nos informan acerca de la existencia de artistas especializados llamados tolteca, nombre que asocia la expresión artística de los mexicas, su creatividad y destreza en el oficio con la herencia de la tradición cultural teotihuacana y tolteca.

Ahora bien, tolteca se refiere a ocupaciones muy diversas. Fray Ber. nardino de Sahagún menciona a los esoultores, pintores, alfareros, especialistas en el trabajo de madera, a los amanteca o plumarios, los techitlahuaque que trabajaban los materiales preciosos, los tlatecque, que eran cortadores de piedra en general, los chalchiuhtlateque o gemntistas, los tlatlalianime o artistas especializados en el trabajo de oro y plata.

Como se dijo, los artistas habitaban en diversos barrios de la ciudad. 
Allí tenían templos dedicados a dioses particulares; se trataba generalmente de deidades protectoras de cada oficio. La patrona, protectora de todos los artistas, fue Xochipilli, y le hacian fiesta en el signo ce océlotl, especialmente los escultores y pintores. Pero, además, participaban en ella también los plateros y los entalladores. Los artistas plumarios tenían por deidad a Coyotlinahual y la celebraban durante el Panquetzaliztli y el tlaxochimaco.

El oficio de artista era hereditario; la primera enseñanza se recibía en el hogar paterno. Al niño se le familiarizaba con el uso y manejo de los materiales, con las texturas y técnicas que iba a utilizar posteriormente Es interesante la representación de esta enseñanza en el Códice Mendocino; según el comentarista, aparecen con sus hijos el carpintero, el lapidario, el pintor, el platero, el plumario; los padres enseñaban sus conocimientos a sus hijos "para que siendo hombres se aplicasen por sus oficios y ocupasen tiempo en cosas de virtud".

Es importante para nosotros mencionar que los hijos de los artistas iban a la escuela llamada calmécac, es decir, aquella adonde acudían también los hijos de los nobles. En cambio, todos los demás macehualtin recibian la educación en el telpochcalli. Si bien esio no es un argumento suficientemente válido para indicar el vínculo de los tolteca con los pipiltin de todos modos nos parece significativo. Cada calpulli tenía su propio calmécac, y el hecho de que el futuro artista frecuentara uno, no significa necesariamente que fuera al más importante, al que estaba ubicado en el recinto del Templo Mayor, sino al que pertenecía al barrio donde vivía. Sin embargo, es interesante señalar que en este aspecto se le otorgaban ciertos privilegios que lo distinguian del macehual común, campesino por lo general. Éste fue uno de tantos reconocimientos y privilegios de los que gozaban por su labor de artistas. Ello no obstante, no se le permitía ascender en la escala social. La asistencia del artista al calmécac pudo haber obedecido también a la necesidad de adciuirir determinada preparación, un adecuado manejo de la iconografía relacionada con los conocimientos de cosmografía y del calendario, por ejemplo.

Para ser un buen artista, además de recibir una educación adecuada, era necesario nacer en una fecha propicia, en un día ce azomatli. Y para lograr un mejor ejercicio de su arte, los aristas ayunaban, preparaban las celebraciones de sus deidades protectoras y ofrendaban una parte de su trabajo. Según dice Clavijero, cuando moría un artista lo vestían con las ropas del dios protector del axte que había ejercido, heredando el oficio a sus hijos. 
Los artistas vivían, como dijimos, en los barrios o calpulli y eran agrupados según los oficios. Generalmente allí mismo estaban sus talleres.

Sin embargo, algunos trabajaban directamente en el palacio, en el Malcalli, o en el Totocalli. En este último se juntaban los artistas plumarios, pintores, escultores, etcétera. Este hecho es muy interesante, pues indica que los materiales y las materias primas que se obtenían del tributo ingresaban al palacio del tlatoani, y alli eran transformados en objetos de arte. Además, la fuerte centralización del poder económico y político del Estado mexica, del cual dependia casi por completo la producción y la reproducción del sistema.

Los artistas se juntaban a veces en luganes públicos en espera de algún encargo especial, por ejemplo, en las plazas públicas. También se xeunían en edificios no muy alejados del palacio, en el Texancalco y Petlacalco o Petlalcalco; en el cuicalli se agrupaban los maestros y mancebos, los tlachcahuan y telpochtlatoque, también en espera que se les ocupase en alguna labor durante el día.

Los escultores trabajaban a veces en el lugar mismo donde se iba a quedar la escultura; otras, en el sitio de procedencia de la piedra, y traían a Tenochtitlan la pieza ya labrada.

Los trabajos artísticos eran organizados generalmente con la participación de varios individuos. Es muy significativa al respecto una figura del Atlas de Durán, que muestra a cuatro escultores labrando la misma piedra. Los maestros de los oficios trabajaban con los aprendices; éstos eran frecuentemente sus propios hijos y ejecutaban las labores preparatorias. Son numerosas las imágenes del Códice Florentino que muestran a los artistas en el momento de practicar su oficio; el artista aparece casi siempre acompañado por lo menos de una persona, y a veces de pequeños grupos hasta de ocho ayudantes ocupados en la obra.

Hubo incluso tareas en las que se necesitaba la colaboración de varios oficios; era común por ejemplo, el trabajo conjunto de los piateros y artistas plumarios.

La ideología de los mexicas, para nosotros, reviste dos aspectos fundamentales y muy precisos: el de expresión de un pensamiento mágicoreligioso, y al mismo tiempo el de la manifestación de un pensamiento político. El arte, como una práctica específica dentro de la ideología, participa de este su carácter general y hace patentes ambos aspectos, que se confunden y entrelazan.

A su vez, la religión mexica trataba de proporcionar una interpretación global del universo natural, sobrenatural y social, y constituye, 
por lo tanto, un lugar común de representaciones en el que se reconocen los miembros de una misma sociedad. Esto dio al arte una apariencia de homogeneidad temática. Los personajes ¿son reales o sobrenaturales? Para nosotros resulta hoy día prácticamente imposible distinguir un tema propiamente religioso; las pinturas del Códice Borbónico, crepresentan a deidades $o$ a sacerdotes del culto? Se confunde lo sacro con lo profano, el mito con la historia.

Los pipiltin, como la clase superior, se apropiaron de la ideología religiosa, y le confirieron un carácter coercitivo y dominante; coercitivo en el sentido económico, político y social, y dominante en cuanto que los pipiltin lo utilizaron para el control social.

De esta manera, los conflictos derivados del dominio de una clase sobre la otra se expresan en el interior de una cosmovisión religiosa que lo transfigura y encubre.

A través de la materialización e instrumentalización de determinados elementos ideológicos - relacionados con el Estado y la religiỏn- puestas en práctica a su vez por el mismo Estado, se satisfacen las necesidades sociales de coerción e integración de la sociedad en su conjunto.

Se impone la religión oficial, y las representaciones de ésta a través de las obras de arte, a las creencias y costumbres de los diferentes calpullis que trataban de preservar su integridad precisamente con una "religión de barrio" y con cultos a deidades particulares. Para responder a esta fragmentación ideológica, el Estado se colocaba por encima de estas unidades y trataba de aglutinarlas en torno a una cosmovisión "místico-guerrera".

\section{a) El carácter privativo de conocimientos}

La función -mediata- de la producción artística en general era destacar ante el pueblo el carácter privativo del saber y, por ende, justificar la posición social de los pipiltin.

Recordemos solamente la existencia e importancia de los códices, cuyo axte y cuya escritura constituyen un claro ejemplo del dominio exclusivo del conocimiento por parte de los nobles. Se puede argumentar que éste no era accesible al pueblo, pero recordemos que la iconografía y las concepciones formales de la pintura mural que decoraba los exte. riores e interiores de los edificios, así como los trabajos en relieve en piedra y madera (pensemos solamente en el "Teocalli de la guerra sagrada" y sus relieves), sí eran visibles. Este dominio exclusivo está 
estrechamente ligado con lo que habíamos mencionado anteriormente: la supervisión de las obras y el tributo de los pipiltin a los dioses.

b) El contenido histórico

Algunas esculturas presentan escenas históricas. Tal es el caso de la "Piedra de Tizoc", que narra las conquistas hechas por este tlatoani. La representación en relieve compuesta por una adición de parejas conquistador-vencido bordea rítmicamente la piedra circular y eleva el acontecimiento al rango de lo casi sobrenatural, ya que las conquistas fueron hechas gracias a la ayuda de los dioses protectores de la guerra. En la obra, se comunica un acontecimiento histórico, pero también (y antes que nada) la valentía y capacidad guerrera del tecuhtli tenochca.

Huehue Motecuhzoma encarga una representación suya en la roca viva de Chapultepec; es un periodo de la historia mexica en el que el gran tlatoani se convierte en poder único, y como hijo predilecto de los dioses desea gloria y memoria personales perpetuas, como un reconocimiento por su gobierno y hazañas. Dice a propósito a su cihuacóatl Tlacaélel que después de haber vencido tantas guerras sería justo erigir una estatua de ambos,

porque quedemos esculpidos para perpetua memoria en premio de nuestros trabajos, para que viendo allí nuestra figura se acuerden de nosotros nuestros hijos y nietos... y se esfuercen a imitarnos.

Para resaltar además su grandeza y su abolengo, algunas veces se incluyen las narraciones sobre la valentía de los antepasados, siempre jefes y nobles.

Hubo en esta época una tendencia a la "deificación" de los altos cirigentes del Estado mexica. Nos parece digno de consideración el hecho de que los tecuhtli, concretamente, Motecuhzoma Ilhuicamina, usara el tocado color turquesa llamado xihuitzolli, propio de las deidades más importantes del panteón mexica, como fueron Tonacatecuhtli, Xiuhtecuhtli y Tlahuitzcalpantecuhtli, entre otros del mismo rango (en el Códice Mendocino).

\section{c) Arte didáctico}

Tanto la escultura (sea de bulto o en relieve) como la pintura mural y otras artes, incluyendo las artes efímeras, tuvieron una importante función didáctica y comunicaban un conocimiento jerarquizado.

Las fachadas de los edificios eran profusamente decoradas con ele- 
mentos pictóricos y escultóricos subordinados a la arquitectura. Sobre los basamentos, en los templos y en los patios, abundaban las esculturas de bulto.

Es muy difícil hoy para nosotros imaginar una ciudad prehispánica como Tenochtitlan luciendo sus edificios de vivos colores cargados de símbolos religiosos; no sólo los muros, sino la misma escultura era a veces recubierta con una capa de estuco y pintada. El gran brasero de Tláloc, encontrado en la parte posterior de la gran pirámide o las cabezas colosales de serpientes que descansan al pie de las escalinatas son testimonio de ello. La grisácea piedra volcánica de la escultura contribuye a acentuar la visión que tenemos de la solemnidad, sobriedad y monumentalidad del arte mexica; "El Macehual", el "Caballero Águila" o la colosal "Coatlicue" del Museo Nacional de Antropología nos hacen pensar en un pueblo austero. Por otra parte, la frialdad del ambiente de museo nos impide imaginar estas mismas piezas en un medio menos hostil, lleno de colorido, de vida y movimiento. Las esculturas grises se combinaban con el resplandor de un piso blanco, muros rojos o azules, adornos de papel, plumas y flores. En un ambiente como éste se desarrollaba la vida cotidiana y las festividades de los tenochcas, rodeados de imágenes, signos y símbolos con los cuales estaban familiarizados y que les eran necesarios. "La función principal de las decoraciones era consagrar o ilustrar, en estos casos el contenido simbólico o representativo, de inscripción religiosa... esto fue su función primordial", dice Pedro Armillas.

\section{Función del arte: comunicación con lo sobrenatural}

Sin embargo, aunque es obvia la importancia de la religión en cuanto a la dominación y coerción social, y la utilización política de la ideologia religiosa, seria una torpeza de nuestra parte plantear la importancia de esta esfera solamente a este nivel. La religión del pueblo mexica era la base misma, la condición necesaria para que se diera tal elaboración.

Es importante comprender que aunque los pipiltin daban un uso politico a esta esfera, eran al mismo tiempo profundamente religiosos y esto se manifiesta, por ejemplo, en función de determinadas obras de escultura y otros productos artísticos, como veremos en seguida.

Como en toda Mesoamérica, en la sociedad mexica todas las artes, incluyendo por supuesto las artes plásticas, estuvieron ritualizadas tanto como cualquier otro medio de comunicación con lo sobrenatural. Su relación con creencias y ceremonias religiosas era estrecha. 
Es importante saber que la religión mexica estaba impregnada de elementos mágicos, es decir, de una disposición activa frente a los dioses. No se rezaba solamente; se realizaban una serie de actos ceremoniales y rituales que constituian el culto, actos que eran parte del tributo mismo a los dioses: sacrificios humanos, autosacrificios, sacrificio de animales, ayunos, cánticos, bailes, tonadas musicales, producción de imágenes de dioses en diferentes materiales, etcétera. Recordemos que el mismo tlatoani se preocupaba por las esculturas tributadas a los dioses para que éstas tuvieran la eficacia necesaria.

El vínculo que existió entre la imagen producida - sea en el mango de un cuchillo de sacrificio recubierto de mosaico, concha y turquesa, o en un teponaxtli de madera con relieves- y el profundo sentimiento religioso del artista dio al arte mexica este carácter de fuerza y monumentalidad; es un arte, antes que nada, vital.

\section{Arte para ser visto por los dioses}

Sabemos por la pluma de los conquistadores que muchas de las esculturas de gran tamaño, al no poder ser utilizadas por los españoles en construcciones coloniales, fueron enterradas para impedir que siguieran los antiguos rituales paganos. Pero enterrar las esculturas y otras piezas que nosotros liamamos artísticas fue una práctica común en toda Mesoamérica, y por supuesto entre los mexicas; desde luego, con fines completamente diferentes.

A veces podian quedar enterradas por accidente o por habérseles puesto encima piezas nuevas (inclusive en la arquitectura, donde un templo quedaba completamente cubier to por una nueva construcción). En el caso de la escultura podemos mencionar la "Gran Coyolxauhqui" del Templo Mayor, que cubrió una imagen más pequeña de la misma diosa. Pero lo interesante es el hecho mismo de que se enterrasen estas magníficas piezas votivas, hechas para los dioses, que formaban parte de un culto.

Mencionaremos aquí un caso diferente: los numerosos objetos que se enterraban junto al difunto, y cuya calidad y cantidad dependía del rango social del personaje. Entre ellos había pequeños ídolos, vasijasefigie, máscaras funerarias, collares de piedras, objetos de oro, concha o piedras preciosas, etcétera. Su finalidad es obvia: acompañar al muerto en el difícil viaje por el inframundo.

Muchas de las esculturas fueron trabajadas en su parte inferior, sobre Ia base misma. Estas representaciones fungían -igual que las enterxadascomo una comunicación con los dioses. Entre ellas tal vez la más cono- 
cida sea la imagen del llamado Mictlantecuhtli, en la base de la conocida escultura monumental de la "Coatlicue" (por cierto, nosotros pensamos que no se trata de Mictlantecuhtli, sino de Tlaltecuhtli, dios de la tierra, a juzgar por los elementos asociados con la imagen). Los relieves en la parte inferior de las esculturas eran una práctica común y mencionaremos solamente otras dos muy conocidas: lo que Edouard Seler ha llamado Atltlachinolli, en la base de la cabeza decapitada de Coyolxauhqui y diversos elementos acuáticos en la figura recostada del Chac Mool procedente de Tacubaya.

Por último, ¿podemos imaginar una escultura tal como la vieron los conquistadores españoles? En Ios templos, recubiertas de las semillas más diversas y untadas de sangre humana. Llamemos belleza o monstruosidad a sus cualidades estéticas, las piezas tenían una dimensión desconocida para nosotros, dimensión que adquirieron en el tiempo en que cumplían una función de eficacia frente a los dioses.

En resumen, este tipo de esculturas o esta producción artística fue destinada fundamentalmente a la comunicación con lo sobrenatural, y ofrecida como tributo a alguna deidad. Eran la expresión de una religiosidad profunda, real y necesaria para que los mexicas pudieran afrontar su existencia ante los poderes de las fuerzas de la naturaleza. Ésta cra su función primordial, inmediata.

\section{Arte efimero}

Mencionaremos aqui también un arte que generalmente se menciona muy poco, pero cuya producción fue muy copiosa y popular. Nos referimos a la producción de imágenes utilizadas en las fiestas; objetos que no han llegado hasta nosotros, ya que por el tipo de material utilizado en su construcción tuvieron una existencia efímexa, pues estaban destinados a ser destruidos en el transcurso del mismo ritual y constituían parte de él. Estas figuras exan llamadas tecuacultin, lo que se traduce por "dioses o su semejanza", porque tecuachilli quiere decir "ídolo o figura". Fueron hechas de semillas de bledo, madera, hule, papel, caña, plumas, conchas de mar, textiles, etcétera. De la importancia que tuvieron estos objetos y sus características sólo podemos darnos cuenta hoy en los códices prehispánicos. Eran parte significativa precisamente de este arte ritual del que hablábamos arriba.

Veamos algunos ejemplos. En la fiesta del Panquetzaliztli, los servidores del culto de la deidad tribal "bajaban del cu trayendo consigo la estatua de Huitzilopochtli cautiva, que era de masa, y llevábanla para 
sus casas y hacían convite con ella a sus parientes y a todos los de su barrio", como narra Sahagún. Del mismo material elaboraban las imágenes de los montes en las fiestas del Tepeilhuitl y del Atemoztli; hacían otras para la ceremonia del llamado bautismo.

Ésta era una práctica general; una costumbre tanto de la nobleza como de la gente del pueblo; aquélla en la fiesta del Huey Micailhuitontli y del Panquetzaliztli, y, ésta en las demás fiestas del calendario ritual. Los señores invitados, jefes de diversos pueblos, aun de los distantes, solamente tenían derecho a observar la práctica ritual, a la vez que la obligación de asistir.

Las razones por las cuales se prefieren las imágenes tienen causas profundas, mágicas, religiosas y rituales; la magia implica y requiere de una participación activa de sus practicantes, de una comunión, tanto por parte de los pipiltin como de los macehualtin. Desde luego -volvemos a insistir - es una práctica también jerarquizada. Una de las maneras de participar en el tiempo sagrado consistía precisamente en rellenar los cuerpos de los ídolos de semillas de bledos o de maíz; en quemar las figuras de hule o papel, etcétera.

Hemos tratado de subrayar que la sociedad mexica se reconocía en un arte que expresaba sus valores propios, y que en él la función de comunicación era más importante que el interés propiamente artístico (al menos en el sentido en que hoy lo entendemos).

Así pues, la producción antística mexica no se redujo de ningún modo a factores económicos y políticos; los incluye, pero al mismo tiempo los rebasa. En realidad es mucho más compleja y rica tanto en sus condiciones de existencia, como en significados sociales . Recrea el medio peculiar de su vida histórica concreta y de su reproducción. Las obras sirven para la comunicación en el doble sentido de identificación entre los miembros de una misma comunidad, y también de creación en la conciencia o en el inconsciente de una modificación de las relaciones con el mundo. Es decir, una función pasiva y otra activa. Las significaciones sociales y cósmicas se asocian con la esfera concreta de la estructura social cuya reproducción está asegurada por el Estado, precisamente mediante el tipo de vínculo y la eficacia de sus diferentes aparatos. Sobra añadir que el aparato ideológico que sostiene la producción artística desempeña en esto un papel fundamental. 